\title{
Dynamic distribution and expression in vivo of the human interferon gamma gene delivered by adenoviral vector Jiangxue $\mathrm{Wu}^{1}$, Xia Xiao ${ }^{1}$, Hongyun Jia1,3, Jiemin Chen ${ }^{1}$, Yinghui Zhu' ${ }^{1}$, Peng Zhao ${ }^{1}$, Huanxin Lin ${ }^{1}$ and Wenlin Huang*1,2
}

\author{
Address: ${ }^{1}$ State Key Laboratory of Oncology in South China, Cancer Center, Sun Yat-sen University, Guangzhou 510060, PR China, ${ }^{2}$ Institute of \\ Microbiology, Chinese Academy of Science, Beijing 100080, PR China and ${ }^{3}$ College of fundamental Medical Science, Guangzhou University of \\ Chinese Medicine, Guangzhou 510006, PR China \\ Email: Jiangxue Wu - gladysw@163.com; Xia Xiao - xiaoyue7604@yahoo.com.cn; Hongyun Jia - hongyun_jia@163.com; \\ Jiemin Chen - cjmhl@163.com; Yinghui Zhu - hey_pigpig@hotmail.com; Peng Zhao - Peng_zhao007@126.com; \\ Huanxin Lin - linhuanxin_888@126.com; Wenlin Huang* - hwenl@mail.sysu.edu.cn \\ * Corresponding author
}

Published: 16 February 2009

BMC Cancer 2009, 9:55 doi:10.1/86/147|-2407-9-55
Received: 10 June 2008

Accepted: 16 February 2009

This article is available from: http://www.biomedcentral.com/147I-2407/9/55

(c) 2009 Wu et al; licensee BioMed Central Ltd.

This is an Open Access article distributed under the terms of the Creative Commons Attribution License (http://creativecommons.org/licenses/by/2.0), which permits unrestricted use, distribution, and reproduction in any medium, provided the original work is properly cited.

\begin{abstract}
Background: We previously found that $r$-hu-IFN $\gamma$ exerts a potent anti-tumor effect on human nasopharyngeal carcinoma xenografts in vivo. Considering the fact that the clinical use of recombinant IFN $\gamma$ is limited by its short half-life and systemic side effects, we developed a recombinant adenovirus, Ad-IFN $\gamma$.

Methods: Dynamic distribution of the adenovirus vector and expression of IFN $\gamma$ were evaluated by Q-PCR and ELISA after intratumoral administration of Ad-IFN $\gamma$ into CNE-2 xenografts.

Results: Ad-IFN $\gamma$ DNA was mainly enriched in tumors where the Ad-IFN $\gamma$ DNA was injected ( $P$ $<0.05$, compared to blood or parenchymal organs), as well as in livers $(P<0.05)$. Concentrations of Ad-IFN $\gamma$ DNA in other organs and blood were very low. Intratumoral Ad-IFN $\gamma$ DNA decreased sharply at high concentrations $\left(9 \times 10^{5}\right.$ copies/ $\mu \mathrm{g}$ tissue DNA $)$, and slowly at lower concentrations $\left(1.7-2.9 \times 10^{5}\right.$ copies/ $\mu$ g tissue DNA). IFN $\gamma$ was detected in the tumors and parenchymal organs. The concentration of IFN $\gamma$ was highest in the tumor $(P<0.05)$, followed by the liver and kidney $(P$ $<0.05$ ). High-level intratumoral expression of IFN $\gamma$ was maintained for at least 7 days, rapidly peaking on day 3 after injection of Ad-IFN $\gamma$ DNA.
\end{abstract}

Conclusion: An IFN $\gamma$ gene delivered by an adenoviral vector achieved high and consistent intratumoral expression. Disseminated Ad-IFN $\gamma$ DNA and the transgene product were mainly enriched in the liver.

\section{Background}

IFN $\gamma$, a homodimeric cytokine produced by $\mathrm{T}$ lymphocytes and natural killer cells, belongs to a family of glycoproteins that have antiviral, immunomodulatory, and anti-proliferative effects. The anti-tumor activities of
IFN $\gamma$ have been shown in various kinds of tumors, such as lymphomas, melanomas, and metastatic renal cell carcinomas [1-4]. Nasopharyngeal carcinoma (NPC) is a malignant disease of the head/neck region that is endemic in Southeast Asia [5]. We have reported that r-hu-IFN $\gamma$ 
treatment exerts anti-proliferative effects in vitro on NPC cells, and leads to a profound anti-tumor effect in vivo [6]. However, although IFN $\gamma$ has shown some promise in preclinical and clinical anticancer studies, it possesses properties that limit its clinical use.

High serum concentrations of IFN $\gamma$ yield significant side effects and toxicities. These side effects include fever, fatigue, nausea, vomiting, neurotoxicity, and leukopenia. In addition, IFN $\gamma$ has a short half-life of elimination, whether given intravenously, subcutaneously, or intramuscularly, and thus requires relatively frequent readministration. These limitations have prompted the investigation of alternate modes of delivering this cytokine to achieve better therapeutic outcomes while minimizing toxicity [1]. Studies have revealed that the most efficient and least toxic delivery system for IFN $\gamma$ is a localized, sustained release dosage form $[1,3,4]$. Therefore, gene therapy with intratumorally injected recombinant adenoviral vectors is a promising approach because it offers the potential to achieve consistent therapeutic gene expression in the tumor $[3,4]$.

In the present study, we developed a recombinant adenovirus, Ad-IFN $\gamma$, encoding human interferon gamma. To determine whether intratumoral administration of AdIFN $\gamma$ could achieve localized sustained expression of IFN $\gamma$, we sought to characterize the biodistribution of the adenoviral vector and transgene expression in the tumor, blood, liver, kidney, heart, brain, spleen, and lung at days $1,2,3,5,7,14$, and 21 after injection. Results indicated that the IFN $\gamma$ gene delivered by adenoviral vector achieved high intratumoral expression, lasting for at least 7 days after injection of Ad-IFN $\gamma$. Disseminated Ad-IFN $\gamma$ DNA and the transgene product were mainly enriched in the liver.

\section{Methods \\ Adenoviral vectors}

E1-deleted, replication-deficient adenoviral vectors based on human adenovirus serotype Ad5 were used to produce the non-replicating adenovirus, Ad-IFN $\gamma$, encoding human interferon gamma [7]. The cDNA for IFN $\gamma$ was inserted into the $\mathrm{E} 1$ region of the adenoviral genome with transgene expression driven by the cytomegalovirus (CMV) promoter. Adenoviruses were propagated in 293 cells (American Type Culture Collection, Manassas, VA, USA), harvested at $48 \mathrm{~h}$ after infection, and purified by cesium chloride gradient centrifugation according to a standard protocol [8], resulting in a particle:pfu ratio of 100:3.32. The viral vectors were stored at $-80^{\circ} \mathrm{C}$ in virus preservation solution ( $10 \%$ glycerol, $0.585 \% \mathrm{NaCl}$, $0.02 \% \mathrm{MgCl}_{2} \cdot \mathrm{H}_{2} \mathrm{O}, 0.01 \mathrm{M}$ Tris- $\left.\mathrm{HCl}, \mathrm{pH} 8.4\right)$ at a concentration of $1 \times 10^{12} \mathrm{VP} / \mathrm{ml}$.

\section{Animals}

Female BALB/c nude mice (4-6 weeks old) were obtained from the Experimental Animal Center (Sun Yat-sen University, Guangzhou, China) and maintained in a specific pathogen-free (SPF) environment. After 1 week of adaptation, mice were inoculated subcutaneously in the scapular region with $2 \times 10^{6} \mathrm{CNE}-2$ cells to generate tumors for subsequent experiments. When tumors reached 5-8 $\mathrm{mm}$ in diameter, mice were randomly assigned to groups (3 mice for each time point). Ad-IFN $\gamma$ (diluted with $0.9 \%$ $\mathrm{NaCl}$ to $100 \mu \mathrm{l}$ ) or vehicle was delivered into the center of the tumor via a single injection with a 30 -gauge needle. The dose used per injection was $1 \times 10^{10} \mathrm{VP} /$ tumor. Samples of blood, tumor, heart, liver, spleen, lung, kidney, and brain were harvested at the indicated time points after virus injection, and stored in aliquots at $-80^{\circ} \mathrm{C}$ for analysis. All the animal experiments were conducted in accordance with "Guidelines for the Welfare of Animals in Experimental Neoplasia".

\section{Quantitative analysis of adenovirus distribution}

Tissue samples (about $50 \mathrm{mg}$ for tissue) were immersed in liquid nitrogen and ground into fine tissue powder in a mortar. Viral DNA was isolated from the tissue powder and whole blood (about $100 \mu \mathrm{l}$ for blood) using a Total DNA Extraction Kit (TIANGEN, Beijing, China).

\section{Quantitative PCR}

Adenovirus copies in the samples were measured by hexon DNA PCR [9]. Primer and probe sequences were: hexon forward primer: 5'-CTTCGATGATGCCGCAGTG-3'; hexon reverse primer: 5'-GGGCTCAGGTACTCCGAGG-3'; hexon probe: 5'-FAM-TTACATGCACATCTCGGGCCAGGAC-TAMRA-3'. Amplification was performed in a $50 \mu \mathrm{l}$ reaction volume under the following conditions: $10 \mathrm{ng}$ of sample DNA, $1 \times$ Taqman Universal PCR Master Mix, 600 $\mathrm{nM}$ forward primer, $900 \mathrm{nM}$ reverse primer, and $100 \mathrm{nM}$ hexon probe. Thermal cycling conditions were: $2 \mathrm{~min}$ of incubation at $50^{\circ} \mathrm{C}, 10 \mathrm{~min}$ at $95^{\circ} \mathrm{C}$, followed by 35 cycles of successive incubations at $95^{\circ} \mathrm{C}$ for $15 \mathrm{sec}$ and $60^{\circ} \mathrm{C}$ for $1 \mathrm{~min}$ [9]. Quantification of adenovirus copy number was performed using a standard curve consisting of dilutions of adenovirus DNA from 1,500,000 to 15 copies in 10 ng of cellular genomic DNA.

\section{Quantitative analysis of IFN distribution}

After being immersed in liquid nitrogen and ground into fine tissue powder in a mortar, tissue samples (about 50 $\mathrm{mg}$ ) were ground with PBS containing Protease Inhibitor Cocktail II (Upstate, Lake Placid, NY, USA). After centrifugation, the supernatants were extracted and stored at $80^{\circ} \mathrm{C}$. IFN $\gamma$ concentrations in the tumor, organ extracts, and plasma samples (about $100 \mu \mathrm{l}$ ) were detected with a human IFN $\gamma$ ELISA kit (R\&D Systems, Minneapolis, MN, USA) according to the manufacturer's recommendations. 

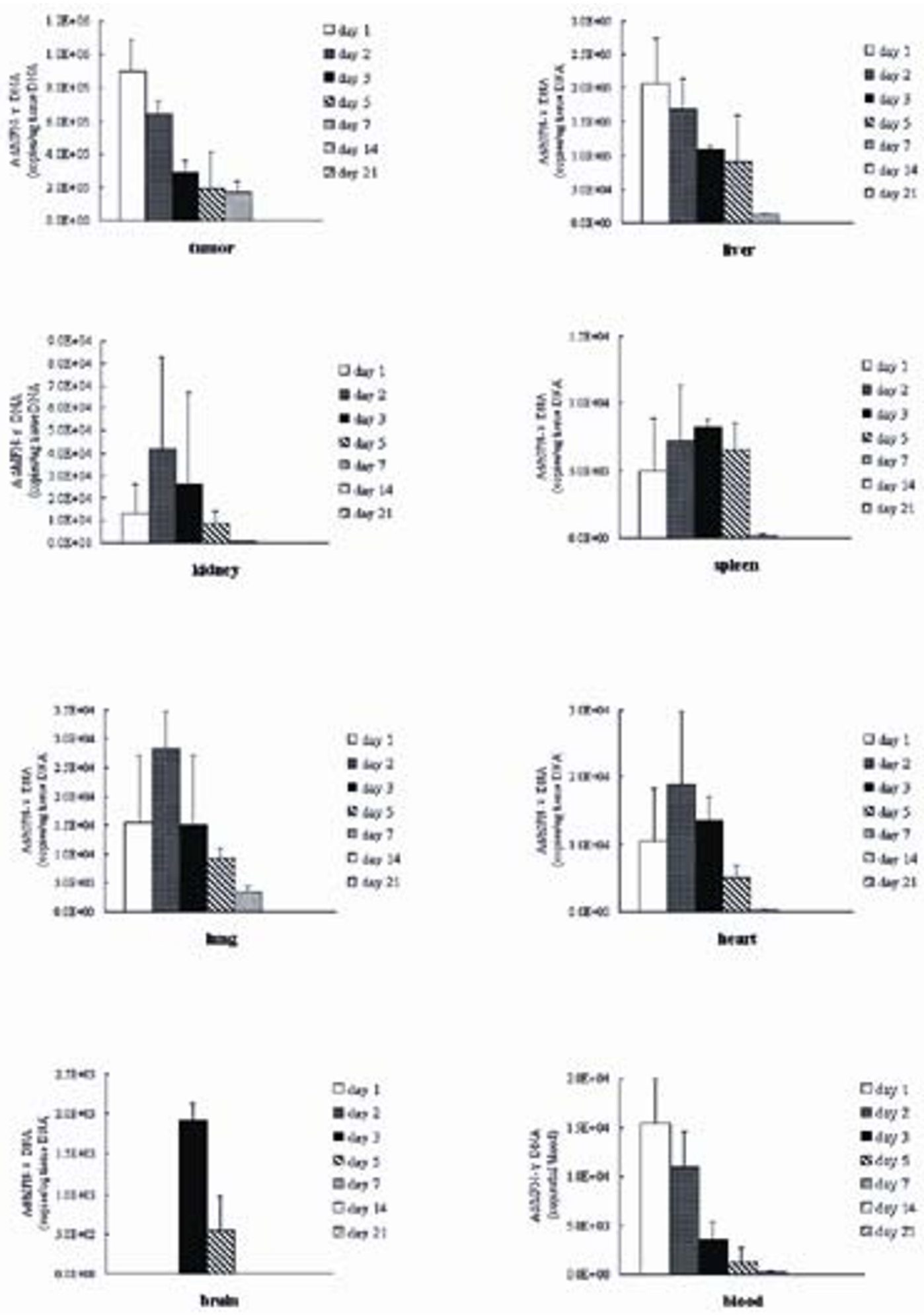

Figure I

Ad-IFN $\gamma$ concentrations in the tumor, heart, liver, spleen, lung, kidney, brain, and blood at different time points after intratumoral injection of Ad-IFN $\gamma$. The dose of injection was I $\times 1010 \mathrm{VP} /$ tumor. Data represent mean \pm SD of three mice. Representative results from two independent experiments are shown. 
Table I: Adenovirus copies in tumors and livers were measured by hexon DNA PCR.

\begin{tabular}{|c|c|c|}
\hline & tumor (copies/ $\mu \mathrm{g}$ tissue DNA) & liver (copies/ $\mu \mathrm{g}$ tissue DNA) \\
\hline day I & $897927.2 \pm 188201.2$ & $206274.7 \pm 67269.5$ \\
\hline day 2 & $645995.1 \pm 76137.4$ & $16853 \mid .6 \pm 46526.4$ \\
\hline day 3 & $289441.2 \pm 75017.3$ & $109217.2 \pm 5478.3$ \\
\hline day 5 & $197677.1 \pm 220320.1$ & $907 \mid 2.8 \pm 68176.5$ \\
\hline day 7 & $169882.6 \pm 69067.4$ & $1 \mid 465.8 \pm 2383.5$ \\
\hline day 14 & 0 & 0 \\
\hline day 21 & 0 & 0 \\
\hline
\end{tabular}

The dose of injection was $1 \times 10^{10} \mathrm{VP} /$ tumor. Data represent mean \pm SD of three mice. Representative results from two independent experiments are shown.

The results were then converted to the concentrations of IFN $\gamma$ in the different tissues based on the sample volume or weight. Sensitivity of the kit was up to $16 \mathrm{pg} / \mathrm{ml}$.

\section{Statistical Analysis}

Results were evaluated using a $t$-test by SPSS 11.0 software (SSPS Inc., Chicago, IL, USA). A $P$ value $<0.05$ was considered statistically significant.

\section{Results}

Systemic distribution of recombinant human IFN adenovirus

$1 \times 10^{10} \mathrm{VP}$ of Ad-IFN $\gamma$ was injected into CNE- 2 tumors. At the indicated time points post-injection, samples of tumor, parenchymal organs, and blood were harvested. To demonstrate adenovirus distribution, fluorescent realtime quantitative PCR was used to quantify viral copies in the samples.

Samples from tumor, heart, liver, spleen, lung, kidney, brain, and blood on days 1, 2, 3, 5, 7, 14 and 21, were tested for the amount of targeted DNA. The copy number of the targeted DNA in samples was deduced according to the standard curves. As shown in Fig. 1, Ad-IFN $\gamma$ DNA was detected in tumor, blood, and parenchymal organs. AdIFN $\gamma$ DNA was mainly enriched in tumors where the AdIFN $\gamma$ DNA was injected $(P<0.05$, compared to blood or parenchymal organs), then in livers $(P<0.05$, compared to blood or other parenchymal organs). Concentrations of Ad-IFN $\gamma$ DNA were very low in other organs and blood (Fig. 1). Ad-IFN $\gamma$ DNA persisted for at least 7 days in the tumors. Intratumoral Ad-IFN $\gamma$ DNA decreased sharply at high concentrations $\left(9 \times 10^{5}\right.$ copies $/ \mu$ g tissue DNA $)$, and slowly at lower concentrations (1.7-2.9 × $10^{5}$ copies/ $\mu \mathrm{g}$ tissue DNA) (Table 1). Ad-IFN $\gamma$ DNA in livers also decreased in a time-dependent manner and became undetectable at day 14 after intratumoral administration (Table 1).

\section{Systemic distribution of human IFN expressed by Ad-IFN}

To evaluate the dynamic expression in vivo of the transgene from the recombinant human IFN $\gamma$ adenovirus, we used ELISA to test the levels of IFN $\gamma$ in samples collected from tumor, heart, liver, spleen, lung, kidney, brain, and blood on days 1, 2, 3, 5, 7, 14, and 21 post-injection of Ad-IFN $\gamma$. IFN $\gamma$ was detected in tumor and parenchymal organs, while IFN $\gamma$ was undetectable in blood (Fig. 2). The concentration of IFN $\gamma$ in tumor was highest $(P<0.05$, compared to blood or parenchymal organs), then in liver and kidney $(P<0.05$, compared to blood or other parenchymal organs). As shown in Fig. 2, intratumoral concentrations of IFN $\gamma$ protein, in contrast to the amount of AdIFN $\gamma$ DNA, rose rapidly and peaked on day 3 after injection of Ad-IFN $\gamma$ DNA, then decreased sharply. On day 14 and 21, only a minimal amount of IFN $\gamma$ remained in the tumor. Concentrations of IFN $\gamma$ in the liver and kidney peaked on day 5. On day 7, IFN $\gamma$ in all tissues decreased dramatically with the exception of maintained high-level expression in the liver. While low levels of IFN $\gamma$ were still present in the liver on days 14 and 21, IFN $\gamma$ in other organs was almost undetectable.

\section{Discussion}

Nasopharyngeal carcinoma is a major malignant disease of the head and neck region that is endemic to Southeast Asia and the Mediterranean basin. NPC affects a predominantly young population and the current treatment regimen of radiation therapy, even combined with cisplatin chemotherapy, yields a 5-year survival rate of approximately $70 \%$. Therefore, evaluation and development of novel therapeutic approaches are critical [9-14]. We had previously found that r-hu-IFN $\gamma$ has direct anti-proliferative effects on all NPC cell lines tested (CNE-1, CNE-2 and C666-1) [6]. Moreover, r-hu-IFN $\gamma$ potently inhibits the growth of CNE-2 and C666-1 xenografts in vivo [6]. Thus, our study revealed that r-hu-IFN $\gamma$ treatment is a promising novel approach for the treatment of NPC. However, the clinical application of recombinant IFN $\gamma$ is limited by the short half-life and the systemic side effects experienced by patients. Therefore, continuous localized release of IFN $\gamma$ is a desirable goal. To overcome these difficulties, we developed a recombinant adenovirus, Ad-IFN $\gamma$. Our results suggested that high and sustained expression of IFN $\gamma$ could be achieved in CNE-2 xenografts, after intratumoral injec- 

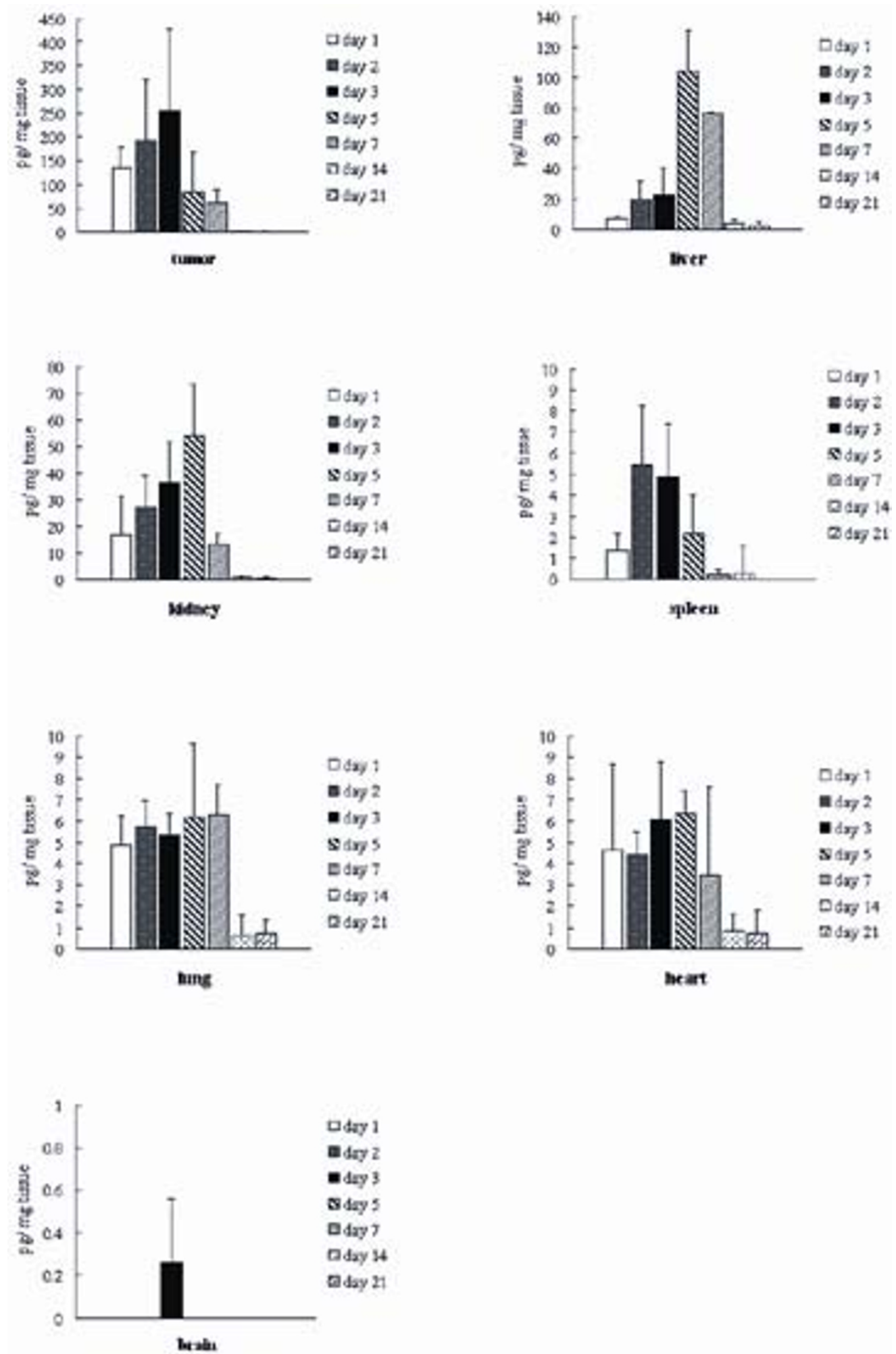

Figure 2

Human IFN $\gamma$ concentrations in the tumor, heart, liver, spleen, lung, kidney, and brain at different time points after intratumoral injection of Ad-IFN $\gamma$. The dose of injection was I $\times 10^{10} \mathrm{VP} /$ tumor. Data represent mean \pm SD of three mice. Representative results from two independent experiments are shown. 
tion of Ad-IFN $\gamma$ (Fig. 2). Consistent with the anti-tumor effects of r-hu-IFN $\gamma$, Ad-IFN $\gamma$ produced a significant dosedependent inhibition of tumor growth in CNE-2 models. Intratumoral administration of Ad-IFN $\gamma$ at doses of $1 \times$ 109 and $5 \times 108 \mathrm{pfu} /$ week for three weeks led to inhibition rates of $67.9 \%$ and $58.64 \%$, respectively [see Additional file 1, Zhu YH, et al., unpublished data].

Intratumoral injection is an advantageous method for local viral gene delivery $[15,16]$. Researchers often assume that viral vectors and transgene expression are confined to solid tumors after the infusion, thereby causing minimal toxicity in normal tissues. However, the dissemination of the viral vector and its encoded gene product could be a serious impediment for vectors that encode cytokine genes, such as IFN $\gamma$, that are not only expressed in situ, but also secreted into the system and have considerable normal tissue toxicity [17-20]. Therefore, we investigated transgene expression in the blood and major organs in this study.

We found that there was potential dissemination of viral DNA and transgene product into parenchymal organs. A significant amount of IFN $\gamma$ was detected in the liver and kidney, which indicated that the clearance of IFN $\gamma$ in vivo is through hepatic metabolism and glomerular filtration. Our results also suggested that most of the disseminated viral DNA was enriched in the liver, which is consistent with reports of efficient uptake of adenovirus by the liver. There was a minimal amount of viral DNA in the blood. One possible explanation for this is that the number of infectious viruses present in the blood was significantly reduced through rapid uptake of the virus by Kupffer cells in the liver [21,22].

Studies have revealed that dissemination of transgene products in normal organs, such as in the liver, may exceed normal tissue tolerance if the products are highly toxic [19]. Toxicological studies conducted in this lab have indicated that intratumoral injection of Ad-IFN $\gamma$ doesn't induce significant toxic effects in mice [unpublished data]. Therefore, adenovirus-mediated intratumoral delivery of the IFN $\gamma$ gene is a promising approach because it achieves high and sustained local IFN $\gamma$ expression in the tumor.

\section{Conclusion}

Adenovirus-mediated intratumoral delivery of the IFN $\gamma$ gene is a promising approach because it achieves high and sustained local IFN $\gamma$ expression in the tumor. Disseminated Ad-IFN $\gamma$ DNA and the transgene product were mainly enriched in the liver.

\section{Competing interests}

The authors declare that they have no competing interests.

\section{Authors' contributions}

JXW, XX, HYJ, JMC, YHZ, PZ and HXL participated in data acquisition. WLH supervised and participated with JXW in the design and coordination of the study. JXW drafted and wrote the manuscript. All authors read and approved the final manuscript.

\section{Additional material}

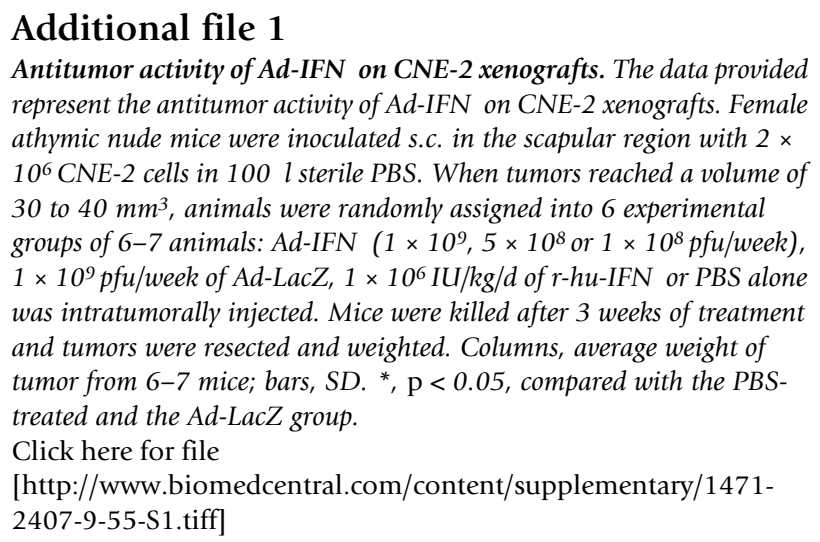
represent the antitumor activity of Ad-IFN on CNE-2 xenografts. Female athymic nude mice were inoculated s.c. in the scapular region with $2 \times$ $10^{6} \mathrm{CNE}-2$ cells in $100 \mathrm{l}$ sterile PBS. When tumors reached a volume of 30 to $40 \mathrm{~mm}^{3}$, animals were randomly assigned into 6 experimental groups of 6-7 animals: Ad-IFN $\left(1 \times 10^{9}, 5 \times 10^{8}\right.$ or $1 \times 10^{8} \mathrm{pfu} /$ week $)$, $1 \times 10^{9} \mathrm{pfu} /$ week of Ad-LacZ, $1 \times 10^{6} \mathrm{IU} / \mathrm{kg} / \mathrm{d}$ of $\mathrm{r}$-hu-IFN or PBS alone was intratumorally injected. Mice were killed after 3 weeks of treatment and tumors were resected and weighted. Columns, average weight of tumor from 6-7 mice; bars, SD. *, $\mathrm{p}<0.05$, compared with the PBStreated and the Ad-LacZ group.

Click here for file

[http://www.biomedcentral.com/content/supplementary/14712407-9-55-S1.tiff]

\section{Acknowledgements}

This work was supported by grants from the State Key Development Program of Basic Research of China (973 Program, No. 2004CB5 I880I), the National High Technology Research and Development Program of China (863 Program, No. 2007AA02 I 202 and 2007AA02 I 203), the National Natural Science Foundation of China (30801360), and Science Funds for Young Scholar of Cancer center of Sun Yat-sen University.

\section{References}

I. Younes HM, Amsden BG: Interferon-gamma therapy: evaluation of routes of administration and delivery systems. J Pharm Sci 2002, 91 (I):2-I7.

2. Pang KR, Wu J, Huang DB, Tyring SK, Baron S: Biological and clinical basis for molecular studies of interferons. Methods $\mathrm{Mol}$ Med 2005, I I 6: I-23.

3. Liu M, Acres B, Balloul JM, Bizouarne N, Paul S, Slos P, et al.: Genebased vaccines and immunotherapeutics. Proc Natl Acad Sci U S A 2004, I 0 I Suppl 2: |4567-I457I.

4. Chada S, Ramesh R, Mhashilkar AM: Cytokine- and chemokinebased gene therapy for cancer. Curr Opin Mol Ther 2003, 5(5):463-474.

5. Chan AT, Teo PM, Huang DP: Pathogenesis and treatment of nasopharyngeal carcinoma. Semin Oncol 2004, 3 I (6):794-80 I.

6. Wu JX, Xiao X, Zhao P, Xue G, Zhu YH, Zhu XF, et al.: MinicircleIFN $\gamma$ Induces Anti-proliferative and Anti-tumoral Effects in Human Nasopharyngeal Carcinoma. Clinical Cancer Res 2006, I 5:4702-13.

7. Zhao P, Zhu Y, Wu J, Liu R, Zhu X, Xiao X, et al.: Adenovirus-mediated delivery of human IFNgamma gene inhibits prostate cancer growth. Life Sci 2007, 8 I(9):695-70I.

8. Graham FL, Prevec L: Methods for construction of adenovirus vectors. Mol Biotechnol 1995, 3(3):207-220.

9. Spano JP, Busson P, Atlan D, Bourhis J, Pignon JP, Esteban C: Nasopharyngeal carcinomas: an update. Eur J Cancer 2003, 39(15):2121-2135.

10. Young LS, Murray PG: Epstein-Barr virus and oncogenesis: from latent genes to tumours. Oncogene 2003, 22(33):5108-5I 21.

II. Wakisaka N, Pagano JS: Epstein-Barr virus induces invasion and metastasis factors. Anticancer Res 2003, 23:2133-2138. 
12. Weinrib L, Li JH, Donovan J, Huang D, Liu FF: Cisplatin chemotherapy plus adenoviral p53 gene therapy in EBV-positive and -negative nasopharyngeal carcinoma. Cancer Gene Ther 200I, 8(5):352-360.

13. Li JH, Lax SA, Kim J, Klamut H, Liu FF: The effects of combining ionizing radiation and adenoviral p53 therapy in nasopharyngeal carcinoma. Int J Radiat Oncol Biol Phys 1999, 43(3):607-616.

14. Li JH, Shi W, Chia M, Sanchez-Sweatman O, Siatskas C, Huang D, et al.: Efficacy of targeted FasL in nasopharyngeal carcinoma. Mol Ther 2003, 8(6):964-973.

15. Lu Y, Carraher J, Zhang Y, Armstrong J, Lerner J, Rogers WP, et al.: Delivery of adenoviral vectors to the prostate for gene therapy. Cancer Gene Ther 1999, 6:64-72.

16. Rein DT, Breidenbach M, Curiel DT: Current developments in adenovirus-based cancer gene therapy. Future Oncol 2006, 2(I): $137-143$.

17. Lohr F, Huang Q, Hu K, Dewhirst MW, Li CY: Systemic vector leakage and transgene expression by intratumorally injected recombinant adenovirus vectors. Clin Cancer Res 200I, 7(II):3625-3628.

18. Paielli DL, Wing MS, Rogulski KR, Gilbert JD, Kolozsvary A, Kim JH, et al:: Evaluation of the biodistribution, persistence, toxicity, and potential of germ-line transmission of a replication-competent human adenovirus following intraprostatic administration in the mouse. Mol Ther 2000, I(3):263-274.

19. Wang Y, Hu JK, Krol A, Li YP, Li CY, Yuan F: Systemic dissemination of viral vectors during intratumoral injection. Mol Cancer Ther 2003, 2(II): I233-1242.

20. Wang Y, Yang Z, Liu S, Kon T, Krol A, Li CY, et al.: Characterisation of systemic dissemination of nonreplicating adenoviral vectors from tumours in local gene delivery. $\mathrm{Br}$ J Cancer 2005, 92(8): $14 \mid 4-1420$.

21. Xu Z, Tian J, Smith JS, Byrnes AP: Clearance of adenovirus by Kupffer cells is mediated by scavenger receptors, natural antibodies and complement. J Virol 2008, 82(23): I I705-I I7I3.

22. Smith JS, Xu Z, Tian J, Stevenson SC, Byrnes AP: Interaction of systemically delivered adenovirus vectors with Kupffer cells in mouse liver. Hum Gene Ther 2008, 19(5):547-54.

\section{Pre-publication history}

The pre-publication history for this paper can be accessed here:

http://www.biomedcentral.com/1471-2407/9/55/prepub
Publish with Bio Med Central and every scientist can read your work free of charge

"BioMed Central will be the most significant development for disseminating the results of biomedical research in our lifetime. "

Sir Paul Nurse, Cancer Research UK

Your research papers will be:

- available free of charge to the entire biomedical community

- peer reviewed and published immediately upon acceptance

- cited in PubMed and archived on PubMed Central

- yours - you keep the copyright
BioMedcentral 